Hurtado was in good health and was recovering from a gastro-intestinal illness. AAAS said that Dr Hurtado and his wife were going to leave Guatemala and were due in the United States within a few days.

The reasons for Dr Hurtado's arrest remain unclear. President Rios Montt, in his television address on $4 \mathrm{July}$, accused Dr Hurtado of being a communist; later, in an interview with a BBC correspondent, Rios Montt charged that "he is not merely a communist but a captain of many units, a member of the leadership group. His son, all his family have been killing people." The US delegates reported that many government officials they spoke to brought up the association of one of Dr Hurtado's daughters with the communist insurgents. She is now living in Nicaragua.

Dr Hurtado may also have come under suspicion for his work among the rural poor. Since 1976, he has run a private clinic offering free health care in San Juan Sacatepequea, an Indian village outside Guatemala City. The delegation doubted

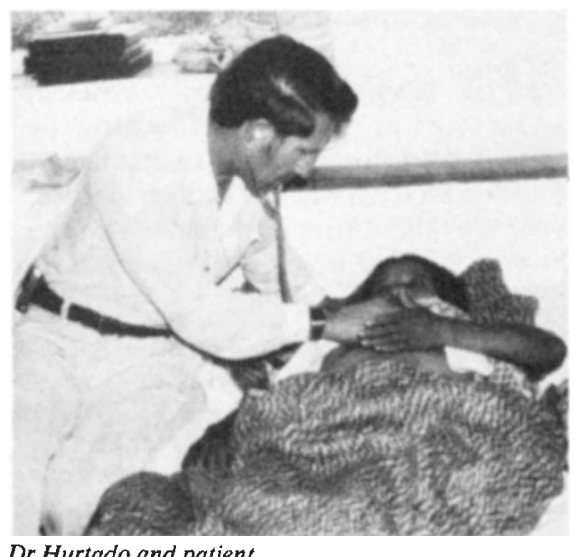

Dr Hurtado and patient

that this was the principal factor behind his arrest, especially since the government has made no effort to shut down the clinic.

The most likely direct motive for his arrest may have been the kidnapping, the day before, of the Interior Minister's son by the Guatemalan communist party. The Interior Minister, or perhaps even a subordinate acting on his own, may have ordered the arrest of Dr Hurtado as a hostage. If so, it was apparently a miscalculation: when the communists issued a list of prisoners whose release they were demanding, Dr Hurtado's name was not on it.

The US delegation, which comprised AAAS, the American Public Health Association, the American Anthropological Association, the National Association of Social Workers and the Institute of Medicine of the National Academy of Sciences, expressed concern that this case may be a bellwether of a return to the repression of the previous regime in Guatemala. President Rios Montt, who came to power in March of this year, pledged to restore civil rights and constitutional law. On 1 July, however, the government declared a "state of siege", suspending all political activity and most civil liberties.

Stephen Budiansky

\title{
Plea from a Soviet refusnik
}

\section{An open letter to Dr J.M. Legay, Secretary General of the World Federation of Scientific Workers.}

SIR - Several times either alone or together with colleagues in the same position (having been refused permission to leave the Soviet Union), I have appealed to you and to the World Federation of Scientific Workers for help. But only recently have we received a reply - and that not directly, but in the pages of Nature (11 February, p.452). I regret to say that your answer was both surprising and disappointing. Being absolutely distressed by it I have to address you once again. Another, perhaps more important reason making me do it is that I am sincerely convinced of your honesty, humaneness and high moral standards anything else would be incompatible with the high position you occupy. Besides, I believe that the contents of your answer suggest that you are not aware of the gravity of the situation of the scientists refused permission to leave the Soviet Union.

For more than 3 years I and my friends have been trying, through completely legal channels, to obtain permission to leave the country. All of us after many months of waiting have been refused permission and in most cases nobody took the trouble of explaining to us the reasons for this refusal. And none of us has ever dealt with military or state secrets. That is why I say that these refusals do not comply with the laws of the Soviet Union, with the International Human Rights Declaration and with the Helsinki Final Act. The only reason for these refusals is the fact that we have scientific degrees. And it has nothing to do with the problem of the notorious "braindrain" since most of us are deprived of any professional work and have been deprived of it ever since we applied for permission to leave the USSR.

I have appealed more than 20 times to different Soviet bodies to cancel the illegal decision and to protect me from lawlessness but I have not received a single answer and the experience of many of my colleagues has been the same. Neither have I received any answer from the vicepresident of the World Federation of Scientific Workers Mr N.N. Inozemtsev or from Mrs Janushevaskaya. But according to the federation's charter, it is their duty to defend the interests of scientists.

Addressing you, Mr Legay, I like many others expect sympathy and help. Maybe it is naive on my part but I consider it your moral duty and that of the federation to help us. It is not a question of me alone, a whole group of scientists is involved. It is not only our careers as scientists, but our whole lives that are threatened. We suffer material hardships and nervous stress beyond any normal limits. We are beginning to break down. Recently one of us, Dr Tsipkin, died after receiving a dismissal notice. Many of us have become seriously ill - and still we have to support aged parents or our children. We are in complete isolation, we are thrown out of society and in fact are not protected by law. And all this for one "fault", for one "crime" - our wish to leave the Soviet Union.

We are living in the world so strikingly depicted by Kafka, but the circumstances of our life are much harder than those of his characters. We have no possibility in our own country to protest openly, publicly. We can't defend our interests legally. We can hope only for help from our western colleagues. This is our only hope, the only thing that makes it possible for us to go on living.

Don't become a silent accomplice of the injustice, don't let evil take the upper hand, raise your voice for us. I want to believe, Mr Legay, that an appeal from you to the Soviet government, an appeal from the World Federation of Scientific Workers and from its journal Scientific World will change our position, will make it possible for us to leave the Soviet Union and to return to scientific work. Don't let our appeal get drowned in bureaucratic holdups and procrastinations.

Only an appeal to the Soviet government can change the situation. The more definite, the more public your stand, the sooner it will help the unfortunate. Take this stand, Mr Secretary General, and like any noble deed it will only add to your and the federation's authority.

You cannot but understand, Mr Secretary General, that our life and our fate have become part of an important problem - that of trust among scientists and their mutual understanding. You have to understand that the question of mutual trust and respect, the questions of scientific contacts will depend on the settlement of our problem. It cannot be right to let general and undoubtedly very important problems obscure the fates of individual people. It cannot be allowed that behind a torrent of beautiful words evil should be committed. Who but the World Federation of Scientific Workers and its head can realize and know it? Who but the federation and its Secretary General can and must stand on guard defending the members deprived of everything?

Moscow

J.S. IRLIN, DSci 